\title{
Review Article \\ Comparative Evaluation of Recombinant Protein Production in Different Biofactories: The Green Perspective
}

\author{
Matilde Merlin, Elisa Gecchele, Stefano Capaldi, Mario Pezzotti, and Linda Avesani \\ Department of Biotechnology, University of Verona, 37134 Verona, Italy \\ Correspondence should be addressed to Linda Avesani; linda.avesani@univr.it
}

Received 6 December 2013; Accepted 10 February 2014; Published 12 March 2014

Academic Editor: Luca Santi

Copyright (C) 2014 Matilde Merlin et al. This is an open access article distributed under the Creative Commons Attribution License, which permits unrestricted use, distribution, and reproduction in any medium, provided the original work is properly cited.

\begin{abstract}
In recent years, the production of recombinant pharmaceutical proteins in heterologous systems has increased significantly. Most applications involve complex proteins and glycoproteins that are difficult to produce, thus promoting the development and improvement of a wide range of production platforms. No individual system is optimal for the production of all recombinant proteins, so the diversity of platforms based on plants offers a significant advantage. Here, we discuss the production of four recombinant pharmaceutical proteins using different platforms, highlighting from these examples the unique advantages of plantbased systems over traditional fermenter-based expression platforms.
\end{abstract}

\section{Introduction}

The market for recombinant pharmaceutical proteins is expanding rapidly. Indeed, nearly all pharmaceutical companies with a market capitalization value of more than \$US 10 billion report that their revenue share from such products is growing faster than the share from small-molecule drugs [1]. The industry has focused on a small number of production platforms based on the bacterium Escherichia coli, several species of yeast, and a selection of insect and mammalian cell lines, which have been developed and improved in line with current good manufacturing practice (cGMP). However, focusing on a small number of platforms means that the unique requirements of certain target proteins are difficult to meet; this is the case of recombinant proteins that are required in small quantities (e.g., for individual patients) or in massive quantities or that need rapid production scale-up. Plant biotechnology can overcome some of these limitations and the potential of plant-based platforms for the flexible, low-cost production of high-quality, bioactive recombinant proteins is well-documented [2].

Plants successfully perform the majority of posttranslational modifications required for the activity of complex eukaryotic proteins and provide tremendous flexibility in terms of scale, cost, safety, and regulatory issues. For example, cell-based bioreactor systems including plant suspension cells and algae are ideal for lower-volume products, whereas field-grown commodity crops can produce metric tons of recombinant protein at highly competitive costs. Contained production systems based on plants have biosafety advantages over microbial and mammalian production platforms because they neither do produce endotoxins nor do they support the growth of pathogens that infect animals, thus reducing purification costs and minimizing the likelihood of facility shutdowns, decontamination issues, and supply limitations that lead to unmet patient/customer demands. Although the costs of downstream processing and purification are comparable in microbial, mammalian, and plantbased platforms, the lower up-front investment required for commercial production in plants and the potential economy of scale provided by cultivation over large areas are key advantages.

This combination of low capital investment, low-cost of goods, and highly scalable manufacturing means that many proteins that are unsuitable for production in fermenters can be produced commercially using plants. Other proteins can be produced more efficiently by fermentation in plant cells because the posttranslational modifications can be engineered to improve product quality and activity. Not all pharmaceuticals will benefit from plant-based systems but the best production platform should be determined 
empirically for each protein using a case-by-case approach. Several recent reviews have discussed the merits of plantmade pharmaceuticals [3], including specific issues related to commercial production [4] and considerations of cGMP issues in plants [5]. This review will focus on four target molecules that highlight different applications across a range of expression systems to illustrate important ways in which plant-based expression platforms are evolving to meet a spectrum of research, development, and commercial needs.

\section{Human Glutamic Acid Decarboxylase}

The $65-\mathrm{kDa}$ isoform of human glutamic acid decarboxylase (hGAD65) is an enzyme containing the prosthetic group pyridoxal $5^{\prime}$-phosphate (PLP). It forms obligate functional dimers and is localized in pancreatic $\beta$-islet cells as well as the brain, where it catalyzes the conversion of glutamate to $\gamma$-aminobutyric acid (GABA) and carbon dioxide. In human cells, the major pool of hGAD65 exists as an autoinactivated apoenzyme [6]. The crystal structure provides insight into both the molecular mechanism of catalytic activity and the structural determinants of its antigenicity [6].

The hGAD65 protein functions as an autoantigen in several autoimmune diseases, including autoimmune type 1 diabetes (T1D) and Stiff-Person syndrome. T1D is strongly associated with autoreactivity to hGAD65. Indeed, hGAD65 autoantibodies are present before the clinical onset of the disease and provide a useful marker to predict the likelihood of its development [7]. The relevance of such markers has been confirmed unequivocally in many laboratories that participate in the Diabetes Autoantibody Standardization Program (DASP), which is a collaboration between the US Centres for Disease Control and Prevention and the Immunology of Diabetes Society [8].

The autoantibodies are not directly pathogenic, whereas $\mathrm{T}$ cells play a dominant role in the initiation and progression of T1D. T-cell responses against the linear epitopes of hGAD65 can be detected in animal models of the disease and in humans at risk of T1D. Studies in animal models have shown that exposure to hGAD65 may induce immunotolerance $[9,10]$. A phase II human clinical investigation, involving genetically predisposed children and young adults with multiple islet cell autoantibodies, is currently exploring whether treatment comprising two injections of $20 \mu \mathrm{g}$ doses of alumformulated hGAD65 (the GAD vaccine, Diamyd Medical) prevents the onset of the disease (NCT01122446).

The prevalence of $\mathrm{T} 1 \mathrm{D}$ in the general population is currently $0.04 \%$, but this is increasing at $3 \%$ per annum in children. If the clinical trial discussed above is successful, then the global demand for recombinant hGAD65 would increase dramatically. GAD65 was initially sourced from porcine brains, although the most abundant source is monkey brain, with a yield of $12 \mathrm{mg} / \mathrm{g}$ [11]. These sources are not suitable for therapeutic GAD65 due to the risk of infection with prions and other pathogens, so heterologous production techniques were investigated following the isolation of hGAD65 cDNA [12].
In all heterologous systems, the yield of hGAD65 is reported by measuring its enzymatic and immunochemical activity. Posttranslational modifications occur in the $\mathrm{N}$ terminal region, that is, blockage of the $\mathrm{N}$-terminal amino group, palmitoylation, and phosphorylation, but none of these modifications are necessary for catalytic activity or immunogenicity so in theory the protein can be produced using any expression platform [11]. Furthermore, the abolition of enzymatic activity to generate a mutant protein (hGAD65mut) does not affect the immunoreactivity of the protein and thus its diagnostic and therapeutic potential [13].

Current commercial platforms for the production of diagnostic and research-grade GAD65 include yeast, baculovirusinfected insect cells, and wheat germ lysates, with costs of $€ 2,000-60,000 / \mathrm{mg}$. The suitability of these different production platforms has been discussed. For example, the expression of GAD65 in bacteria produced a misfolded protein that was primarily localized in inclusion bodies, and it was only possible to produce a soluble and immunogenic product by expressing the protein as an N-terminal fusion with thioredoxin or glutathione S-transferase $[14,15]$. As well as making the protein soluble, the fusion partners also facilitated protein isolation, resulting in yields of up to $12.5 \mathrm{~g} / \mathrm{L}$.

Recombinant hGAD65 has also been expressed in baby hamster kidney (BHK) cells (Heinaes et al., unpublished data), Chinese hamster ovary $(\mathrm{CHO})$ cells, and mouse myeloma cells, the latter resulting in the highest yield of $1.7 \mathrm{mg} / \mathrm{L}$ [16]. Although the overall yield was lower than achieved in bacteria, the recombinant protein was soluble and retained its native structure without a fusion partner. $\mathrm{CHO}$ cells have therefore been used to study the subcellular trafficking and localization of hGAD65.

Recombinant hGAD65 has also been expressed in the yeasts Saccharomyces cerevisiae and Pichia pastoris, both of which produced an active protein with yields of up to $3.52 \mathrm{mg} / \mathrm{L}$ [17]. Insect cells infected with baculovirus vectors achieved the highest yields of hGAD65 ever reported, in the best cases reaching $50 \mathrm{mg} / \mathrm{L}$ [18], but when hGAD65 was expressed with a C-terminal $\mathrm{His}_{6}$ tag, the yield dropped to 3-5 mg/L [19].

Several plant-based platforms have also been used to produce hGAD65. Chlamydomonas reinhardtii chloroplasts were transformed with an hGAD65 vector and the immunoreactive recombinant protein accounted for $0.3 \%$ of the total soluble protein (TSP) in the algal cells [20]. Immunoreactive and enzymatically active hGAD65 has also been expressed in tobacco and carrot plants albeit with disappointing yields; for example, in $\mathrm{T} 1$ tobacco plants, the yield was $10.5 \mu \mathrm{g} / \mathrm{g}$ fresh weight (FW) in the leaves [21-23].

The production of hGAD65 in plant- and insect cellplatforms was achieved by expressing the catalytically inactive version, hGAD65mut, which retains its immunogenicity. The mutant protein accumulates to higher levels than its active counterpart, that is, up to $143.6 \mu \mathrm{g} / \mathrm{g} \mathrm{FW}$ in tobacco leaves [23]. The hGAD65mut mutant was generated by substituting the lysine residue that binds the cofactor PLP with an arginine residue (K396R). It was proposed that the wild-type version of hGAD65 interferes with plant cell metabolism to suppress its own synthesis, whereas the catalytically inactive 
version escapes such feedback and accumulates to higher levels.

Other modified versions of GAD65 have been expressed, including a soluble form generated by substituting the $\mathrm{N}$ terminal domain with the homologous region of the soluble $67-\mathrm{kDa}$ isoform of the protein. This substitution increased the yields of the protein from 3.52 to $12.16 \mathrm{mg} / \mathrm{L}$ in $S$. cerevisiae [17] and from 10.5 to $50 \mu \mathrm{g} / \mathrm{g}$ in tobacco leaves [24]. Although differences in the stability of the $\mathrm{N}$-terminal $\alpha$-helical regions could theoretically account for these differences, there was no improvement to the yield of hGAD65mut in plants when the modification was included [25]. This suggests that abolishing the membrane interactions by removing the $\mathrm{N}$ terminal region does not cause any additional benefit when the biological activity of the protein is eliminated.

Modifying the protein for retention in the endoplasmic reticulum (ER) of plant cells did not increase its yield in transgenic tobacco plants [25]. GAD67/65mut was also expressed in the seeds of three different species (Arabidopsis, tobacco, and petunia) and retained in the ER. The highest yield of $4.5 \mathrm{mg} / \mathrm{g}$ dry weight (DW) was achieved in Arabidopsis seeds [26].

The purification of hGAD65 from yeast, insect, and mammalian cells is usually achieved by immunoaffinity chromatography using anti-GAD monoclonal antibodies [16, 27], anion- exchange chromatography [18], or a combination of the two [17]. In bacteria and yeast, higher yields were achieved by expressing tagged fusion proteins and using the tag as the affinity ligand $[15,19,28]$. Although the purification of hGAD65 has not been reported in plants, edible plant tissues containing the protein can be administered by oral delivery such that extensive purification is not required. It has been demonstrated that the oral administration of a crude transgenic tobacco extract containing hGAD65, in combination with interleukin-4 (IL-4), diminished the peripheral immune response to a subsequent systemic challenge with the same autoantigen by inducing oral tolerance [21].

\section{Norwalk Virus-Like Particles}

Norwalk virus (NV) is the prototype human norovirus (NoV), which contains a single-stranded, positive-sense nonenveloped RNA genome containing three open reading frames and a polyadenylate tail [29]. The NV capsid is a $38 \mathrm{~nm}$ icosahedral structure assembled from 90 dimers of $\mathrm{VP} 1$, the $58-\mathrm{kDa}$ capsid protein (CP), with $T=3$ symmetry $[30,31]$. NoV belongs to a group of highly infectious viruses that are responsible for more than $95 \%$ of epidemic outbreaks of viral gastroenteritis in adults in developed and developing countries [32]. In the USA alone, NoV causes $\sim 21$ million infections per year, resulting in 70,000 hospitalizations and 800 deaths, at a cost of \$US 5.5 billion [33] (https://www.bcm.edu/molvir). In developing countries, $\mathrm{NoV}$ is responsible for up to 1.1 million hospitalizations annually and 218,000 deaths among children [32].

The increasing recognition of $\mathrm{NoV}$ as a disease agent, the absence of a specific treatment, and the limited success in preventing disease outbreaks have led to the evaluation of virus-based vaccines [34]. However, the insufficient quantity of virus particles available for analysis has delayed the development of such a vaccine. The only natural source of NV particles is human stools, which characteristically contain very low concentrations of viruses [29].

The successful cloning, sequencing, and expression of the major NV capsid protein VP1 in insect cells were a major breakthrough and showed that recombinant VP1 folds spontaneously into empty Norwalk virus-like particles (NVLPs) that are stable following lyophilization at temperatures of up to $55^{\circ} \mathrm{C}$ and/or when exposed to acids ( $\mathrm{pH} \mathrm{3-7)} \mathrm{[35].} \mathrm{The}$ recombinant NVLPs remain immunogenic and interact with cellular receptors, eliciting a strong host immune response against the virus $[29,31,36,37]$, and would therefore make ideal NV vaccine candidates [38, 39].

Preclinical studies showed that recombinant NVLPs are immunogenic when administered by the parenteral [29], oral $[40,41]$, and intranasal routes [42]. Furthermore, a specific formulation for intranasal delivery, comprising NVLP dry powder and a novel plant-derived polysaccharide with gelling properties (GelSite), showed superior immunogenicity in mice than in a liquid formulation including an adjuvant [43].

In phase I studies, orally administered NVLPs were found to be safe but only modestly immunogenic as determined by measuring serum antibody levels and counting specific antibody-secreting cells (ASCs) [44-46]. Conversely, a nasally delivered NVLP formulation including an adjuvant was well tolerated and highly immunogenic [47]. A phase I/II study carried out by LigoCyte Pharmaceuticals showed that two $50 \mu \mathrm{g}$ intranasal doses of NVLPs protected mice against challenge with a homologous virus [48]. Furthermore, parenteral administration in phase I/II studies demonstrated that two $100 \mu \mathrm{g}$ intramuscular doses of NVLP vaccine were well tolerated and produced a clinically relevant impact on the incidence of $\mathrm{NV}$ after challenge, as well as the severity in breakthrough cases (Takeda Pharmaceuticals USA Inc., 2013). Collectively, these clinical trials indicated that vaccination may be useful to prevent disease caused by the NoV strains most commonly associated with infection in humans. If future clinical trials confirm the efficacy of the NVLP vaccine in humans, large amounts of NVLPs will be needed to facilitate global vaccination campaigns.

The development of an effective NV vaccine has been hindered by the lack of an animal model for virus production and the inability to grow the whole virus in cell culture. Several expression systems have therefore been tested for the production of NVLPs, including baculovirus-infected insect cells, bacteria, yeast, mammalian cells, and plant-based systems. These production platforms have been investigated by electron microscopy to confirm the fact that the Norwalk virus coat protein (NVCP) self-assembles into NVLPs. Furthermore, the immunogenicity of the recombinant NVLPs has been investigated in animals.

The first attempt to produce NVCP in a heterologous system involved baculovirus-infected insect (Spodoptera frugiperda) cells (Sf9). NVLPs similar in size and appearance to native capsids were detected and, although no expression data were reported, the yield of purified protein ranged from 65 to $125 \mathrm{mg}$ per liter of infected insect cell cultures [29]. 
NVCPs representing different NV strains have also been expressed in E. coli as fusion proteins with maltose binding protein (MBP) and thioredoxin. The yields of the purified fusion proteins were 26 and $56 \mathrm{mg} / \mathrm{L}$, respectively, but no NVLPs were detected. The unassembled purified capsid proteins were analyzed to determine the possibility of establishing an immunologic detection system for NoV antigens, based on the enzyme-linked immunosorbent assay (ELISA), and confirming the diagnosis of NoV-infected patients using recombinant NVCP [49].

NVCP was successfully expressed in P. pastoris system after testing a range of expression vectors and culture conditions. Recombinant NVCP spontaneously formed NVLPs with final yield of $5-10 \mathrm{mg} / \mathrm{L}$ after purification. The yeastderived NVLPs were tested as potential NV oral vaccines by feeding raw yeast extracts to animals. Even at doses as low as $0.1 \mathrm{mg}$, the yeast-derived NVLPs were able to induce significant systemic and intestinal mucosal responses in the animals [50].

Venezuelan equine encephalitis (VEE) virus replicon particles (VRPs) have been used as vectors to express NVCPs in BHK cells, resulting in the production of NVLPs with yields of approximately $10^{10}$ partially purified particles per $\mathrm{mL}$ [51]. VRPs can be used both as vectors to generate NVLPs in heterologous systems or as a self-replicating vaccine that produces recombinant NVLPs in target cells. Mice inoculated subcutaneously with these particles (two doses, $10^{7}$ infectious units each) developed systemic and mucosal immune responses to NVLPs, as well as heterotypic antibody responses to the major capsid protein from a different $\mathrm{NV}$ strain [52].

NVLPs have also been produced in many plant-based systems, with initial experiments focusing on constitutive expression in transgenic plants. Recombinant NVCP selfassembled into NVLPs that accounted for $0.23 \%$ of TSP in transgenic tobacco leaves [41] and NVCPs also accumulated to $0.37 \%$ of TSP in transgenic potato tubers $(34 \mu \mathrm{g} / \mathrm{g}$ of tuber weight) although only $\sim 50 \%$ self-assembled into NVLPs. The oral immunogenicity of partially purified NVLPs from tobacco and potato was demonstrated in mice [41], whereas phase I clinical studies in humans demonstrated that the administration of uncooked potatoes containing NVLPs was safe, but only modestly immunogenic [45].

A modified NVCP gene, codon-optimized for plants, was later expressed in tomato and potato, resulting in the accumulation of NVCP at levels of up to $8 \%$ TSP in tomato fruits and $0.4 \%$ TSP in potato tubers, corresponding to $160 \mu \mathrm{g} / \mathrm{g}(100 \mu \mathrm{g}$ NVLPs/g) in tomato fruits and $120 \mu \mathrm{g} / \mathrm{g}$ $(90 \mu \mathrm{g}$ NVLPs/g) in potato tubers. Freeze-dried potato and tomato tissues were immunogenic when fed to mice, but the delivery of the same doses of air-dried tomato fruit stimulated stronger immune responses. It was proposed that air-drying preserves the stability of NVLPs and the fruit tissue structure, thus conferring greater protection against proteolytic enzymes in the gut [53].

More recently, MagnICON vectors have been used for the rapid and efficient production of NVLPs in Nicotiana benthamiana plants. Different subcellular localizations were compared, and the highest yields were achieved by cytosol targeting ( $860 \mu \mathrm{g}$ NVCP/g FW in the leaves) at 12 days after infection (dpi). The partially purified recombinant NVLPs were orally immunogenic when fed to outbreed CD1 mice [54].

The agroinfiltration of $N$. benthamiana leaves with an optimized DNA replicon from bean yellow dwarf virus resulted in efficient replicon amplification and robust NVCP production within 5 days. The NVCP yield was $\sim 340 \mu \mathrm{g} / \mathrm{g} \mathrm{FW}$ in the leaves and the protein assembled efficiently into NVLPs [55]. The same expression vector was recently used in lettuce, which produces low levels of secondary metabolites. This resulted in average NVCP yield of $200 \mu \mathrm{g} / \mathrm{g} \mathrm{FW}$ in the leaves [56]. The production of NVLPs in N. benthamiana plants has also been optimized using Agrobacterium-mediated transient gene expression for the simultaneous expression of two NV capsid proteins (VP1 and VP2) to increase NVLP stability, along with the Pepper mild mottle virus suppressor of viral posttranscriptional gene silencing. This achieved yields of up to $1 \mathrm{mg}$ of partially purified NVLPs per $\mathrm{g} \mathrm{FW}$ in the leaves [57].

The purification of NVLPs is usually achieved by using ultracentrifugation and density gradient methods that exploit particle size and density regardless of the expression platform $[29,41,46,51,54,55,57]$. However these methods are technically demanding and difficult to scale up, so alternative processing strategies have been explored $[50,56,58]$. Low-pH precipitation coupled with DEAE anion-exchange chromatography recently allowed the efficient purification of NVLPs from N. benthamiana leaves [59]. This was the first report to describe the scaled-up production of a pharmaceutical-grade (cGMP-compliant) NVCP vaccine in plants, and the product is currently being tested in a phase I human clinical trial.

\section{Monoclonal Antibody 2G12}

The monoclonal antibody ( $\mathrm{mAb}) 2 \mathrm{G} 12$ is a broadly neutralizing anti-HIV-1 human IgG1 that recognizes a high-mannose glycan cluster on the surface of the virus glycoprotein 120 (gp120). It was isolated from an asymptomatic HIV-1 infected patient in 1990, and in 1994 its neutralizing activity against HIV-1 strains and its ability to bind with gp120 were described for the first time [60,61]. The broad biological activity of $2 \mathrm{G} 12$ allows it to defend against infection with primary HIV isolates from various clades, either by direct virus neutralization or by combination with other effector cells and complement activation [62].

As well as neutralizing HIV-1 in vitro, passive transfer studies in primates demonstrated that 2G12 can control infection and prevent transmission in vivo following parenteral or mucosal administration, preferably in combination with other neutralizing antibodies $[63,64]$. A phase I study in humans demonstrated the safety of repeated intravenous infusions of 2 G12 combined with another broadly neutralizing antibody (2F5) when administered to asymptomatic patients infected with HIV-1 $[65,66]$. Moreover, 2G12 combined with two broadly neutralizing antibodies (2F5 and 
4E10) was able to delay viral rebound in patients whose infections were fully suppressed by antiretroviral treatment before antibody administration [67]. A phase II trial was then carried out to investigate the pharmacokinetic properties of the antibodies in the cocktail [68]. Such approaches require large doses of recombinant antibody (7-14 g of each antibody per patient) and thus create an immense demand, given that $\sim 35$ million people were living with HIV in 2012 (UNAIDS, 2013).

Broadly neutralizing human monoclonal antibodies such as 2 G12 can also be applied as a mucosal microbicide to prevent HIV infection [69]. A recombinant form of $2 \mathrm{G} 12$ produced in stable transformed tobacco plants has been tested in a phase I clinical trial, based on intravaginal administration of the antibody to healthy female subjects at a dose range of 7-28 mg per individual (NCT01403792). Future trials will test the efficacy of prophylaxis in humans [70].

The complex and glycosylated structure of 2G12 means that it must be produced in eukaryotic expression platforms and then tested in specific assays to confirm its in vitro antigen-binding and neutralization capacity. The molecule was initially produced in hybridoma clones, generated by the electrofusion of B-cells and CB-F7 myeloma cells, producing $10 \mathrm{pg}$ of the antibody per cell per day [60]. The mRNA for the 2G12 heavy and light chains was isolated and transcribed into cDNA in 1998 [71]. Large-scale antibody production was then achieved in $\mathrm{CHO}$ cells and the antibody was purified by protein A affinity chromatography. For most in vivo studies and clinical trials, 2G12 IgG1 was manufactured by Polymun Scientific Immunbiologische Forschung $\mathrm{GmbH}$ (Vienna, Austria) under cGMP guidelines, at a cost of $€ 350-500 / \mathrm{mg}$. Uniquely, the $2 \mathrm{G} 12$ prepared for clinical trial NCT01403792 was manufactured in tobacco leaves using a novel cGMP process.

HIV microbicides must be effective, safe, user-friendly, and above all economically affordable in the developing world, which has the highest number of HIV patients. Plants are ideal for the production of such low-margin/highdemand antibodies because of the economy of scale offered by agricultural production. This concept was developed in the EU project Pharma-Planta, which achieved the expression of 2 G12 in several plant species and the fast-track development of transgenic tobacco as the primary production platform. The use of many different plants showed that the species, tissue, and subcellular compartment could affect the structure and composition of the antibody glycans, but this had no significant impact on the HIV-neutralization capacity of the antibody in vitro [72].

A secreted form of $2 \mathrm{G} 12$ has been constitutively expressed in the leaves of wild-type Arabidopsis plants [73] and in a mutant strain modified to knock out the genes encoding $\beta 1,2$-xylosyltransferase (XT) and core $\alpha 1,3$-fucosyltransferase (FT), thus producing complex $\mathrm{N}$-glycans lacking plantspecific residues [74]. The yield of the antibody was $0.05-0.2 \%$ of TSP in these young plants. The secreted and ER-retained versions of $2 \mathrm{G} 12$ were also produced in Arabidopsis seeds, achieving yields of 3.6 and $2.1 \mathrm{mg} / \mathrm{g} \mathrm{DW}$, respectively [75]. In the same series of experiments, the secreted form of $2 \mathrm{G} 12$ was also produced in the seeds of the XT/FT knockout line [75].
Cereals are considered more suitable for the production of recombinant proteins in developing countries because dry seeds preserve recombinant proteins in a stable form without a cold chain, and maize has been widely used for the production of pharmaceutical proteins in this context. A secreted form of $2 \mathrm{G} 12$ was expressed in the endosperm of the elite maize cultivar M37W and the best-performing line was passed through to a dedifferentiation-regeneration cycle, producing seeds yielding more than $100 \mu \mathrm{g}$ of the antibody per gram DW and eliminating most of the seedto-seed variation [76]. HIV-neutralization assays showed that maize-derived 2 G12 was nearly three times more potent than its $\mathrm{CHO}$-derived counterpart, probably reflecting the higher proportion of aggregates (which are known to be more efficient than monomeric antibodies in terms of neutralization efficacy). The same antibody has also been retained in the ER of maize endosperm cells by adding a C-terminal KDEL tag to both antibody chains, resulting in its accumulation in ER-derived zein protein bodies [70]. These experiments were carried out using the cultivar Hill, but since this variety has little agronomic relevance, it was backcrossed to elite starch germplasms and a sugar-type sweetcorn background. The average yield in the T3 generation was $38.8 \mu \mathrm{g} / \mathrm{g}$ DW, with a maximum of $60 \mu \mathrm{g} / \mathrm{g} \mathrm{DW}$. As above, the plant-derived antibody was more potent in neutralization assays than the same antibody produced in $\mathrm{CHO}$ cells.

The 2G12 antibody has also been produced by transient expression in $N$. benthamiana leaves, initially using three glycoengineered lines in which RNA interference (RNAi) was used to suppress the synthesis of xylosylated and/or core $\alpha 1,3$-fucosylated glycan structures [77]. A binary vector carrying the cDNA sequences of both antibody chains was used for agroinfiltration and the yield was $110 \mu \mathrm{g} / \mathrm{g}$ FW (corresponding to approximately $0.5 \%$ TSP) in the leaves. Similarly, N. benthamiana leaves were coinfiltrated with two binary vectors, one encoding the two antibody chains and the other carrying the p19 silencing suppressor gene [78]. Secreted and ER-retained forms of the antibody were produced with yields of $\sim 100 \mu \mathrm{g} / \mathrm{g}$ FW in the leaves at $6 \mathrm{dpi}$, increasing until $18 \mathrm{dpi}$. There was a small reduction in antigen-binding activity compared to $2 \mathrm{G} 12$ from CHO cells, probably reflecting the presence of residual impurities, but as above the HIV-neutralization capacity was higher. The 2G12 antibody has also been transiently expressed in N. benthamiana leaves using replicating and nonreplicating systems based on deleted versions of Cowpea mosaic virus (CPMV) RNA-2 [79]. In both cases, secreted and ER-retained versions of the antibody were expressed, yielding 14.8 and $37.8 \mu \mathrm{g} / \mathrm{g}$ FW, respectively, using the replicating vector and 66.7 and $123.8 \mu \mathrm{g} / \mathrm{g}$ FW, respectively, using the nonreplicating vector. The resulting antibody once again showed a marginally lower affinity for its antigen but similar or marginally better neutralization activity compared to $2 \mathrm{G} 12$ produced in $\mathrm{CHO}$ cells.

Tobacco has been used both for the transient and stable expression of 2G12. The secreted and ER-retained forms were transiently expressed in tobacco leaves coinfiltrated with Agrobacterium tumefaciens vectors containing expression constructs for the heavy and light chains, achieving yields 
of $80-100 \mu \mathrm{g} / \mathrm{g} \mathrm{FW}$ in the leaves [78]. The ER-retained form was expressed stably in transgenic tobacco leaves, accounting for $0.4 \%$ of TSP in the mature leaves [80]. As above, subsequent assays showed that the plant-derived antibody bound its antigen more weakly but neutralized HIV more potently than the $\mathrm{CHO}$-derived counterpart. The expression of $2 \mathrm{G} 12$ in tobacco seeds achieved yields of $0.3 \%$ TSP, and immunolocalization studies demonstrated that the antibody accumulated in protein storage vacuoles (PSVs). The seedderived antibody showed significantly lower antigen-binding activity than the leaf-derived protein, probably reflecting genetic segregation and thus the generation of a significant proportion of seeds expressing the heavy chain alone.

Finally, 2G12 has also been expressed in tobacco cell suspension cultures prepared from cultivar BY-2 [81]. Optimization of the nitrogen supply increased the yield to $12 \mathrm{mg} / \mathrm{L}$ by day 7 of the fermentation process. The antibody was secreted into the medium but a proportion also accumulated within the cells. The antigen-binding activity of the fully secreted antibody was $83 \%$ compared to the $\mathrm{CHO}$ counterpart (set arbitrarily at $100 \%$ ), whereas that of the intracellular fraction was $40 \%$. This probably reflects the fact that the intracellular antibody is a heterogeneous mixture containing all forms of the antibody at different stages of maturation, folding, and assembly, whereas only the fully folded and assembled version is secreted into the medium.

Several strategies have been proposed to improve the yield and stability of plant-derived recombinant proteins and reduce the costs of processing [2]. For example, the use of elastin-like polypeptides (ELPs) as fusion partners can increase the solubility and stability of recombinant proteins and facilitate purification by a process termed inverse transition cycling (ITC) [82]. Different versions of 2 G12 have been expressed constitutively in transgenic tobacco leaves and seeds by fusing one or both antibody chains to ELPs, increasing the yields to $1 \%$ TSP [80]. Subsequent characterization of the purified antibodies demonstrated that the ELP fusion does not interfere with antibody assembly in tobacco and endows the recombinant antibody with greater antigenbinding activity albeit at the expense of HIV-neutralization efficacy. In the absence of a convenient fusion partner, the purification of antibodies such as 2 G12 usually involves protein A affinity chromatography, an expensive processing option which achieves a recovery of $50-85 \%$ depending on the platform but is an expensive processing option. Therefore, additional nonprotein A protocols have been developed based on traditional chromatography methods, and these can achieve a recovery rate of $50-60 \%$ and a purity of up to $90 \%$ (e.g., $[76,83])$.

\section{Human Interleukin-6}

Human interleukin-6 (hIL-6) is a $26-\mathrm{kDa}$ secreted glycoprotein from the multifunctional cytokine family, which has diverse physiological roles including the induction of the acute phase response and inflammation, the regulation of the immune response, and the promotion of B-cell differentiation into immunoglobulin-secreting cells [84]. The hIL6 protein is also considered a myokine, that is, a cytokine produced by muscle cells in response to muscle contraction and physical exercise, stimulating lipolysis as well as fat oxidation [85, 86]. The overproduction of hIL-6 and other proinflammatory cytokines is associated with severe chronic immunemediated inflammatory diseases (IMIDs) such as rheumatoid arthritis [87] and atherosclerosis [88]. The disruption of hIL-6 expression also occurs during the neurodegenerative process in Alzheimer's disease [89] and high levels of this molecule are associated with several hyperproliferative diseases and with the progression of cancer [90,91].

The hIL- 6 protein was first isolated from the supernatant of a T-cell line known as TCL-Nal, which is transformed with Leukemia virus-1 [92], and its biochemical and functional characteristics were subsequently investigated [92, 93]. Native mature hIL-6 has two disulfide bonds and an Nglycosylation site at Asn73, although the glycan appears to be nonessential for biological activity. The activity of the protein can be evaluated in vitro by testing the stimulation of $\operatorname{IgM}$ production by SKW6-CL4 B-cells transformed with EpsteinBarr virus (EBV) [92] or the proliferation of mouse BALB/c lymphocytes or the hIL-6-dependent murine hybridoma cell lines B9 or MH60 [94].

Recombinant antibodies and synthetic peptides that target hIL6 and prevent interaction with its receptor (hIL6R) are useful therapeutic candidates in rheumatoid arthritis, systemic-onset juvenile idiopathic arthritis (soJIA), and Castleman's disease $[95,96]$. The development of such therapeutic molecules requires large quantities of functional hIL-6 but only small amounts of the native protein can be isolated from lymphocyte cultures, that is, $\sim 3 \mu \mathrm{g}$ of pure protein from $5.7 \mathrm{~L}$ of culture medium [92]. The high cost of the recombinant protein produced in E. coli $(\sim € 10,000-15,000 / \mathrm{mg})$ means that alternative platforms must be considered. Thus far, recombinant hIL-6 has been produced in E. coli, $P$. pastoris, baculovirus-infected insect cells, and tobacco plants.

The first attempts to express hIL-6 in E. coli involved the use of a pT9-11-derived plasmid with the inducible Trp promoter [97]. In attempting to express the mature protein with no signal peptide, trace amounts of hIL-6 were detected but no significant overexpression was observed. The first 20 amino acids of mature IL-2 (already overexpressed successfully in bacterial cells) were then added to the hIL-6 $\mathrm{N}$-terminus along with a kallikrein cleavage site. The chimeric protein was expressed at high levels within inclusion bodies, with a final yield of $0.4 \mathrm{~g} / \mathrm{L}$. The mature form of hIL- 6 was subsequently expressed as inclusion bodies using a synthetic gene with a codon-optimized N-terminal portion, with a final yield of $0.55 \mathrm{~g} / \mathrm{L}$ and an estimated purity of $\sim 60 \%[98,99]$.

Two different approaches have been used to produce soluble hIL-6 in E. coli, one using an expression system designed to secrete the protein into the periplasmic space [100] and the other by fusing the protein to the secretion signal of bacterial $\alpha$-hemolysin signal peptide for secretion into the culture medium [101]. In both cases, the protein was produced in a soluble and active form but with low yields $(10 \mathrm{mg} / \mathrm{L}$ and $70 \mu \mathrm{g} / \mathrm{L}$, resp.). Soluble hIL-6 was subsequently expressed in E. coli strain BL21 as a fusion with MBP, thioredoxin, ubiquitin, or NusA, although only the MBP and 
NusA fusion constructs were successful. The maximum yield was $7.5 \mathrm{~g} / \mathrm{L}$ in a bioreactor culture optimized for the NusA variant [102]. The authors did not report any attempt to remove the tag from the fusion protein and did not provide any information about the biological activity of the molecule.

More recently, a set of hIL-6 constructs with combinations of $\mathrm{N}$ and/or C terminal tags $\left(\mathrm{His}_{6}, \mathrm{~T}\right.$, GST, and the $E$. coli alkaline phosphatase periplasmic secretion signal) were expressed in different E. coli strains with reducing BL21 or oxidizing Origami 2 cytoplasmic environments, at different growth/induction temperatures, in the presence or absence of helper plasmids encoding cytoplasmic chaperones [103]. The highest yield of soluble hIL- 6 was $2.6 \mathrm{mg} / \mathrm{L}$ and was achieved by expressing cytoplasmic hIL- 6 in BL21 cells at $22^{\circ} \mathrm{C}$ in the presence of chaperones. The recombinant protein was active as shown by its ability to stimulate murine hybridoma cells.

Recombinant hIL-6 has also been expressed successfully in large-scale cultures of the methylotrophic yeast $P$. pastoris [104]. The mature protein cDNA was cloned in frame with the yeast $\alpha$-factor secretion signal under the control of the inducible $A O X 1$ promoter (pPICZalphaA vector) and introduced into $P$. pastoris strain X33. Several culture and expression conditions were tested, both in shake flasks and in the large-scale bioreactor. The highest yield was achieved $96 \mathrm{~h}$ after induction, reaching 30 and $280 \mathrm{mg} / \mathrm{L}$ in the shake flasks and bioreactor, respectively. The molecular mass of the purified hIL- 6 was $\sim 20.9 \mathrm{kDa}$, indicating the absence of glycosylation. The bioactivity of hIL-6 produced in P. pastoris was five-fold higher than that of the commercial recombinant hIL-6 produced in E. coli when used to stimulate the growth of $\mathrm{BALB} / \mathrm{c}$ mouse lymphocytes.

The first attempt to produce recombinant hIL-6 in baculovirus-infected insect cells involved the expression of full-length hIL-6 cDNA in a modified Autographa californica nuclear polyhedrosis virus (AcNPV) vector. This was used to transfect $\mathrm{Sf} 9$ cells, yielding modest amounts of a $22-\mathrm{kDa}$ protein after $72 \mathrm{~h}$, and partial purification of the protein was necessary to establish its biological activity [105]. Functional hIL-6 was subsequently expressed in baculovirus-infected Sf9 cells using a system based on inducible secretion, but the low yields $(1 \mu \mathrm{g} / \mathrm{mL})$ were disappointing [106].

The production of a functional recombinant hIL-6 in transgenic tobacco plants was first reported by [107] but the yield was not determined. More recently, Nausch et al. [108] compared different transient and stable expression strategies for hIL-6 in tobacco and N. benthamiana. Stable expression was tested using three different constructs targeting the apoplast, ER, and vacuole, each controlled by the constitutive Cauliflower mosaic virus (CaMV) $35 \mathrm{~S}$ promoter. The ERretained version of hIL-6 accumulated to much higher levels (an order of magnitude higher) than the proteins targeted to the apoplast and vacuole, and the ER-retention construct was therefore selected. The three best-performing T0, expressing the ER-retained hIL-6, were self-pollinated to obtain T1 and T2 progeny, increasing the yield in the best-performing line to $1397 \mu \mathrm{g} / \mathrm{g}$ TSP (112 $\mu \mathrm{g} / \mathrm{g}$ FW in leaves) and $1212 \mu \mathrm{g} / \mathrm{g}$ TSP $(303 \mu \mathrm{g} / \mathrm{g}$ DW in seeds), respectively. The same construct was then used for transient expression in two tobacco cultivars and in $N$. benthamiana with the MagnICON system. Two different MagnICON systems were used, one based on the RNA-dependent RNA polymerase from Turnip vein clearing virus (TVCV) and the crucifer-infecting tobacco mosaic virus coat protein (cr-TMV/TVCV) and the other based entirely on Potato virus $X$ (PVX). By using the cr-TMV/TVCV system, only cell-to-cell movement was observed in all the three host plants, whereas by using the PVX system the infection spreads systemically in N. benthamiana [109] but not in the two tobacco cultivars. The highest yields were achieved in $N$. benthamiana, where hIL- 6 accumulated to $7.8 \%$ of TSP using the cr-TMV/TVCV system and $4.8 \%$ of TSP using the PVX system. Significantly lower values were achieved in tobacco, with a maximum yield of $\sim 1 \%$ of TSP in the cultivar Virginia. The structural and biological properties of the recombinant proteins were tested by western blot analysis, revealing that plant-derived hIL-6 is present as two glycoforms $(26-27 \mathrm{kDa})$ although no comparisons were made to the glycan structure on the native hIL- 6 molecule. The activity of recombinant hIL-6 was tested by applying crude leaf extracts to mouse B-9 cells and performing a hybridoma proliferation assay, indicating that the activity of the plant-derived proteins was equivalent to the aglycosylated commercial standard hIL-6 produced in E. coli [94].

The processing strategy for hIL-6 is strongly dependent on the nature of the starting material. The insoluble hIL-6 recovered from $E$. coli inclusion bodies must undergo several solubilization/refolding steps based on the redox coupleassisted oxidation of cysteine residues, followed by a dilution or gel filtration refolding step. Additional ion exchange, reversed phase HPLC, and size exclusion chromatography steps may be used to increase product purity. Although highly pure (up to 99\%) active hIL-6 can be recovered using these methods, the efficiency is often low, with a recovery rate of 15-20\% [99]. The large number of purification steps and low final yield in these protocols is not cost-effective for industrial manufacturing, so a simpler protocol was developed for the isolation of soluble hIL-6 produced in P. pastoris [104]. Here the protein was purified from the culture supernatant by PEG precipitation, followed by anion-exchange and size exclusion chromatography, with a final yield of $56 \%$ and a purity of up to $95 \%$. No purification strategy has yet been published for hIL-6 produced in plants.

\section{Conclusions}

In this review, we discuss the production of four recombinant proteins (hGAD65, NVLPs, 2G12, and hIL-6) which represent heterogeneous pharmaceutical applications, different biochemical features, and a corresponding wide range of production platforms. Table 1 overviews the production of the target proteins in "traditional" heterologous expression systems. We have focused not only on the yields achieved in different production systems but also on the unique properties of the manufacturing process for each protein, thus highlighting the advantages of plant-based systems over fermenters for specific niche markets. This leads to the conclusion that plants are potentially most beneficial for 
TABLE 1: Highest yields of the expression of the four selected recombinant pharmaceutical proteins in "traditional" heterologous production platforms.

\begin{tabular}{|c|c|c|c|}
\hline Recombinant protein & Heterologous expression system & Highest expression level & Reference \\
\hline \multirow{5}{*}{ hGAD65 } & Escherichia coli & $12.5 \mathrm{mg} / \mathrm{mL}$ & {$[15]$} \\
\hline & Saccharomyces cerevisiae & $0.46 \mathrm{mg} / \mathrm{mL}$ & {$[27]$} \\
\hline & Pichia pastoris & $0.42 \mathrm{mg} / \mathrm{mL}$ & {$[27]$} \\
\hline & Spodoptera frugiperda cells & $0.02 \mathrm{mg} / \mathrm{mL}$ & {$[18]$} \\
\hline & Mouse myeloma cells & $1.67 \mathrm{mg} / \mathrm{L}$ & {$[16]$} \\
\hline \multirow{4}{*}{ NVCP } & Escherichia coli ${ }^{*}$ & $56 \mathrm{mg} / \mathrm{L}$ & [49] \\
\hline & Pichia pastoris ${ }^{*}$ & $10 \mathrm{mg} / \mathrm{L}$ & {$[50]$} \\
\hline & Spodoptera frugiperda cells* & $125 \mathrm{mg} / \mathrm{L}$ & {$[29]$} \\
\hline & Baby hamster kidney cells* & $10^{10}$ particles $/ \mathrm{mL}$ & [51] \\
\hline $2 \mathrm{G} 12$ & Hybridoma clones & $10 \mathrm{pg} / \mathrm{cell} /$ day & {$[60]$} \\
\hline \multirow{3}{*}{ hIL-6 } & Escherichia coli & $7.5 \mathrm{mg} / \mathrm{mL}$ & {$[102]$} \\
\hline & Pichia pastoris & $0.28 \mathrm{mg} / \mathrm{mL}$ & {$[104]$} \\
\hline & Spodoptera frugiperda cells & $0.001 \mathrm{mg} / \mathrm{mL}$ & {$[106]$} \\
\hline
\end{tabular}

${ }^{*}$ Reported values are the highest yield data of purified or partially purified recombinant protein because of the absence of expression data.

the production of four major categories of pharmaceutical proteins:

(1) pharmaceutical proteins required in large quantities, that is, commodity pharmaceutical proteins such as microbicide components;

(2) pharmaceutical proteins that need to be produced rapidly, that is, rapid-response proteins such as vaccines against rapidly evolving viral strains;

(3) biopharmaceuticals that require complex posttranslational modifications, that is, antibodies and recombinant proteins with specific glycan structures;

(4) biopharmaceuticals intended for oral delivery.

Other plant-derived recombinant proteins, beyond the four targets described here, also fit in these categories, for example, vaccines against seasonal virus strains (e.g., fulllength hemagglutinin protein from the A/Wyoming/03/03 (H3N2) strain of influenza, [110]), personalized vaccines (e.g., non-Hodgkin's lymphoma vaccines for individual patients, [111]), and proteins carrying specific glycans that increase their efficacy (e.g., human glucocerebrosidase for enzyme replacement therapy, [112]).

The large-scale production of recombinant pharmaceutical proteins is often hampered by the poor expression of their mature, active forms in prokaryotic hosts such as E. coli and by the high costs and the limited scalability of traditional fermenter-based platforms using mammalian cells. One of the most interesting issues that emerge from our case-by-case analysis is the high productivity of plants compared to other platforms when both the intrinsic yield (per unit biomass) and biomass yield (per hectare per year) are taken into account. This advantage is shown in Table 2 for the four case studies considered in this paper, in terms of the number of plants needed to produce $1 \mathrm{~g}$ of each target protein. The variety of available plant hosts and expression systems provide diverse toolbox for the manufacture of recombinant proteins. However, it is not a straightforward process to select the ideal plant-based expression system because many aspects need to be considered carefully, including product yields, quality, production scalability, costs, and cGMP compliance.

In our case studies, the highest yields were achieved in transgenic tobacco plants and by transient expression in $N$. benthamiana. For example, hGAD65 is expressed at higher levels in $N$. benthamiana than in tobacco (27.6 versus $10.5 \mu \mathrm{g} / \mathrm{g} \mathrm{FW}$ ) but stably transformed tobacco plants are more productive overall because they produce much more biomass. Furthermore, the accumulation of hGAD65mut in tobacco leaves exceeds the levels achieved in N. benthamiana (143.6 versus $96.6 \mu \mathrm{g} / \mathrm{g} \mathrm{FW}$ ), thus suggesting that the productivity would be higher in tobacco even without considering the enhanced biomass production [23]. Conversely, the accumulation of hIL-6 in N. benthamiana is up to 80-fold more than achieved by stable expression in tobacco leaves and seeds [102].

Meaningful comparisons among different platforms are required for proper evaluation but this is complicated by the diverse units used to report expression data. In our four case studies, yields were reported both in absolute units (mass of recombinant protein per unit of biomass, which allows total productivity to be calculated by factoring in the production scale) and in relative units (\%TSP) which is less useful particularly when comparing dissimilar tissues such as leaves and seeds with vastly different water contents. If the costs of downstream processing are assumed to be the same for all platforms, the estimated costs for the manufacture of recombinant proteins in plants are much lower than current fermentation-based technologies because of the lower upstream costs [56]. For example, a 140-fold cost saving was estimated for the production of hGAD65 in transgenic tobacco compared to baculovirus-infected insect cells [23].

In addition to the flexible and cost-effective manufacturing offered by plants generally, transient expression systems offer the further advantage of rapid upscaling due to the short interval between transformation and expression. We used 
TABLE 2: Best-performing plant-based platforms for the production of four selected recombinant pharmaceutical proteins.

\begin{tabular}{|c|c|c|c|c|c|c|}
\hline Plant host & Plant organ & Recombinant protein & $\begin{array}{l}\text { Expression } \\
\text { system }\end{array}$ & $\begin{array}{l}\text { Highest } \\
\text { expression level }\end{array}$ & $\begin{array}{c}\text { Plants/g } \\
\text { recombinant } \\
\text { protein }\end{array}$ & Reference \\
\hline \multirow{7}{*}{$\begin{array}{l}\text { Tobacco (Nicotiana } \\
\text { tabacum) }\end{array}$} & \multirow{4}{*}{ Leaves } & hGAD65mut & Transgenic & $0.14 \mathrm{mg} / \mathrm{g}$ LFW & ${ }^{1} 93$ & {$[23]$} \\
\hline & & NVCP & Transgenic & $0.2 \% \mathrm{TSP}$ & ND & {$[41]$} \\
\hline & & IL6_KDEL & Transgenic & $0.11 \mathrm{mg} / \mathrm{g}$ LFW & ${ }^{1} 119$ & [108] \\
\hline & & 2G12/2G12_KDEL & $\begin{array}{c}\text { Transient } \\
\text { (binary vector) }\end{array}$ & $0.1 \mathrm{mg} / \mathrm{g} \mathrm{LFW}$ & ${ }^{1} 133$ & {$[78]$} \\
\hline & \multirow{3}{*}{ Seeds } & hGAD67/65mut & Transgenic & $0.4 \mathrm{mg} / \mathrm{g}$ DSW & ${ }^{1} 1250$ & {$[26]$} \\
\hline & & IL6_KDEL & Transgenic & $0.3 \mathrm{mg} / \mathrm{g}$ DSW & ${ }^{1} 1667$ & {$[108]$} \\
\hline & & 2G12_KDEL/ELP & Transgenic & $1.0 \%$ TSP & ND & {$[80]$} \\
\hline \multirow{4}{*}{ Nicotiana benthamiana } & \multirow{4}{*}{ Leaves } & hGAD65mut & $\begin{array}{c}\text { Transient } \\
\text { (MagnICON } \\
\text { vectors) }\end{array}$ & $0.1 \mathrm{mg} / \mathrm{g} \mathrm{LFW}$ & ${ }^{2} 3451$ & {$[23]$} \\
\hline & & NVCP (VP1 and VP2) & $\begin{array}{c}\text { Transient } \\
\text { (binary vector) }\end{array}$ & $1 \mathrm{mg} / \mathrm{g}$ FLW & ${ }^{2} 333$ & {$[57]$} \\
\hline & & IL6_KDEL & $\begin{array}{c}\text { Transient } \\
\text { (MagnICON } \\
\text { vectors) }\end{array}$ & $7.8 \% \mathrm{TSP}$ & ND & [108] \\
\hline & & 2G12_KDEL & $\begin{array}{l}\text { Transient (viral } \\
\text { vector) }\end{array}$ & $0.12 \mathrm{mg} / \mathrm{g}$ LFW & ${ }^{2} 2693$ & [79] \\
\hline \multirow{3}{*}{ Arabidopsis thaliana } & \multirow{2}{*}{ Seeds } & hGAD67/65mut & Transgenic & $4.5 \mathrm{mg} / \mathrm{g}$ DSW & ${ }^{3} 308$ & {$[26]$} \\
\hline & & $2 \mathrm{G} 12$ & Transgenic & $3.6 \mathrm{mg} / \mathrm{g} \mathrm{DSW}$ & ${ }^{3} 385$ & {$[75]$} \\
\hline & Leaves & $2 \mathrm{G} 12$ & Transgenic & $0.2 \%$ TSP & ND & {$[73]$} \\
\hline Maize (Zea mays) & Seeds & $2 \mathrm{G} 12$ & Transgenic & $>0.1 \mathrm{mg} / \mathrm{g}$ DSW & ND & {$[76]$} \\
\hline Lettuce (Lactuca sativa) & Leaves & NVCP & $\begin{array}{l}\text { Transient (viral } \\
\text { vector) }\end{array}$ & $0.2 \mathrm{mg} / \mathrm{g} \mathrm{LFW}$ & ND & {$[56]$} \\
\hline Petunia (Petunia hybrida) & Seeds & hGAD67/65mut & Transgenic & $0.2 \mathrm{mg} / \mathrm{g}$ DSW & ND & [26] \\
\hline Carrot (Daucus carota) & Taproots & hGAD65 & Transgenic & $0.01 \%$ TSP & ND & {$[22]$} \\
\hline Chlamydomonas reinhardtii & & hGAD65 & Transgenic & $0.3 \%$ TSP & ND & {$[20]$} \\
\hline $\begin{array}{l}\text { Potato plant (Lycopersicon } \\
\text { esculentum) }\end{array}$ & Fruits & NVCP & Transgenic & $\begin{array}{l}0.16 \mathrm{mg} / \mathrm{g} \text { fruit } \\
\text { weight }\end{array}$ & ${ }^{4} 0.6$ & {$[53]$} \\
\hline $\begin{array}{l}\text { Tomato (Solanum } \\
\text { tuberosum) }\end{array}$ & Tubers & NVCP & Transgenic & $\begin{array}{c}0.12 \mathrm{mg} / \mathrm{g} \text { tuber } \\
\text { weight }\end{array}$ & ND & {$[53]$} \\
\hline
\end{tabular}

The highest expression levels are reported as mass of recombinant protein per unit of biomass (LFW: leaves, fresh weight; DSW: dry seed weight) unless these values were not available, in which case percentage total soluble protein (\%TSP) is used instead. The recombinant protein productivity values were calculated by considering the seed or leaf biomass yield per plant $\left({ }^{1}[115] ;{ }^{2}[59] ;{ }^{3}[116] ;{ }^{4}\right.$ Mississippi State University website: http://msucares.com/crops/comhort/yield.html). ND: not determined (values were not calculated because of the absence of productivity data or the expression data were reported as \%TSP).

the Norwalk virus vaccine as a case study to highlight this niche. An effective vaccine needs to be produced quickly after strain identification in order to halt the spread of the new strain. NVLPs produced by transient expression address these issues, allowing the rapid and affordable production of strainspecific vaccines in a timely manner and in relevant locations, including the developing world $[54,55,59,110]$. However, it should also be borne in mind that plants offer advantages for small-scale expression. For example, the production of personalized vaccines in mammalian cells would require a full production campaign and the "occupation" of a fermenter for each patient requiring a vaccine. In contrast, transient expression in plants would allow many similar vaccines to be prepared by using a small number of plants each enclosed in a protective chamber in a greenhouse. In this manner, the production of a customized idiotype vaccine for nonHodgkin's lymphoma was achieved in less than two weeks from biopsy by using transient expression in plants [111, 113].

Another key advantage of plant-based expression platforms is their ability to synthesize complex eukaryotic glycan structures. Approximately one-third of approved biopharmaceuticals is thought to be glycoproteins, which favors the use of eukaryotic systems for such products [114]. Although $\mathrm{N}$-glycan synthesis in the ER is conserved among eukaryotes, $\mathrm{N}$-glycan processing in the Golgi body differs among phyla resulting in diverse glycan structures. Plant-derived glycoproteins typically contain non-human-glycans that are added in the Golgi body [114]. Whether these glycans are immunogenic or allergenic is still a matter of debate, but they can be immunoreactive [70]. 
Two of the target proteins considered in this review are glycosylated: 2 G12 and hIL-6. The antibody 2 G12 has been expressed in a wide range of plant-based platforms, including wild-type and glycoengineered systems, and has been targeted to different subcellular compartments, thus resulting in a huge variety of glycoforms. The detailed description of these data is beyond the scope of this paper, but overall it was found that the different glycan profiles do not affect the virus-neutralization activity of the antibody in vitro [72]. The impact of the different glycoforms in vivo should be considered in future studies, but it is likely that Fc-mediated antibody effector functions and antibodydependent cell-mediated cytotoxicity could be influenced by different glycans and this should be considered in the context of systemic antibody administration [70]. Plantderived hIL-6 was also produced as a number of different glycoforms, all of which had the same in vitro activity as the aglycosylated commercial counterpart produced in bacteria, but similarly the in vivo implications need to be evaluated. These considerations are less important if plant-derived pharmaceuticals are intended for topical application [117]. Importantly, plant-specific glycans may also be desirable in specific cases. For example, the presence of terminal mannose residues on plant-derived recombinant glucocerebrosidase was shown to increase its uptake by macrophages and thus its efficacy for the treatment of Gaucher's disease [112].

One final and unique advantage of plant-based systems is the natural "bioencapsulation" provided by edible plant organs when pharmaceuticals are intended for oral administration $[45,118]$. The oral delivery of drugs is preferred [119] but unprotected peptides and proteins are exposed to the harsh gastrointestinal environment, which is acidic and rich in proteolytic enzymes. For oral vaccination, several phase I clinical trials have been carried out using edible plants, including those expressing NVLPs as discussed above [45]. These trials confirmed the safety and immunogenicity of NVLPs without the need for a buffer or vehicle other than the plant cell. Transgenic plants expressing antigens may therefore be a significant step towards the goal of developing cost-effective and user-friendly vaccines.

The oral route is also a potentially effective strategy for the prevention of autoimmune diseases by inducing tolerance. For example, the oral administration of plant tissue expressing hGAD65 (in combination with IL-4) to the nonobese diabetic mouse model of T1D effectively prevented the onset of the disease [21]. However, the clinical application of oral tolerance strategies in humans would be challenging because of the immense cost of autoantigen production, particularly if repeated regular doses are required to maintain the beneficial effects. Plants could meet this unprecedented demand for recombinant autoantigens, making such strategies safe, palatable, and economically feasible.

The examples discussed above can be considered proofof-principle case studies that highlight some of the specific advantages of plant-based production platforms over traditional systems. It is unlikely that plants will completely replace $\mathrm{CHO}$ cells and other established systems, but they are now gaining a firm foothold in niche markets where the unique benefits of plants offer the greatest advantages.

\section{Conflict of Interests}

The authors declare that there is no conflict of interests regarding the publication of this paper.

\section{Authors' Contribution}

Matilde Merlin and Elisa Gecchele are equal contributors to this paper.

\section{References}

[1] M. Goodman, "Pharmaceutical industry financial performance," Nature Reviews Drug Discovery, vol. 8, no. 12, pp. 927928, 2009.

[2] R. M. Twyman, S. Schillberg, and R. Fischer, "Optimizing the yield of recombinant pharmaceutical proteins in plants," Current Pharmaceutical Design, vol. 19, no. 31, pp. 5486-5494, 2013.

[3] M. J. Paul, A. Y. The, R. M. Twyman, and J. K. Ma, “Target product selection-where can Molecular Pharming make the difference?" Current Pharmaceutical Design, vol. 19, no. 31, pp. 5478-5485, 2013.

[4] R. Fischer, S. Schillberg, J. F. Buyel, and R. M. Twyman, "Commercial aspects of pharmaceutical protein production in plants," Current Pharmaceutical Design, vol. 19, no. 31, pp. 54715477, 2013.

[5] R. Fischer, S. Schillberg, S. Hellwig, R. M. Twyman, and J. Drossard, "GMP issues for recombinant plant-derived pharmaceutical proteins," Biotechnology Advances, vol. 30, no. 2, pp. 434-439, 2012.

[6] G. Fenalti, R. H. P. Law, A. M. Buckle et al., "GABA production by glutamic acid decarboxylase is regulated by a dynamic catalytic loop," Nature Structural \& Molecular Biology, vol. 14, no. 4, pp. 280-286, 2007.

[7] S. Baekkeskov, H.-J. Aanstoot, S. Christgau et al., "Identification of the $64 \mathrm{~K}$ autoantigen in insulin-dependent diabetes as the GABA-synthesizing enzyme glutatmic acid decarboxylase," Nature, vol. 347, no. 6289, pp. 151-156, 1990.

[8] J. S. Petersen, T. Dyrberg, A. E. Karlsen et al., "Glutamic acid decarboxylase (GAD65) autoantibodies in prediction of $\beta$-cell function and remission in recent-onset IDDM after cyclosporin treatment. The Canadian-European Randomized Control Trial Group," Diabetes, vol. 43, no. 11, pp. 1291-1296, 1994.

[9] D. L. Kaufman, M. Clare-Salzler, J. Tian et al., "Spontaneous loss of T-cell tolerance to glutamic acid decarboxylase in murine insulin-dependent diabetes," Nature, vol. 366, no. 6450, pp. 6972, 1993.

[10] R. Tisch, X.-D. Yang, S. M. Singer, R. S. Liblau, L. Fugger, and H. O. McDevitt, "Immune response to glutamic acid decarboxylase correlates with insulitis in non-obese diabetic mice," Nature, vol. 366, no. 6450, pp. 72-75, 1993.

[11] Y. Inoue, K. Ishii, M. Miyazaki, and H. Ueno, "Purification of L-glutamate decarboxylase from monkey brain," Bioscience, Biotechnology and Biochemistry, vol. 72, no. 9, pp. 2269-2276, 2008.

[12] R. J. Wyborski, R. W. Bond, and D. I. Gottlieb, "Characterization of a cDNA coding for rat glutamic acid decarboxylase," Molecular Brain Research, vol. 8, no. 3, pp. 193-198, 1990.

[13] C. S. Hampe, L. P. Hammerle, L. Bekris et al., "Recognition of glutamic acid decarboxylase (GAD) by autoantibodies from 
different GAD antibody-positive phenotypes," The Journal of Clinical Endocrinology \& Metabolism, vol. 85, no. 12, pp. 46714679, 2000.

[14] M. L. Papouchado, S. N. Valdez, M. R. Ermácora, S. Gañan, and E. Poskus, "Highly-sensitive and specific enzyme-linked immunosorbent assays for GAD65 autoantibodies using a thioredoxin-GAD65 fusion antigen," Journal of Immunological Methods, vol. 207, no. 2, pp. 169-178, 1997.

[15] K. M. Davis, T. Foos, C. S. Bates et al., "A novel method for expression and large-scale production of human brain Lglutamate decarboxylase," Biochemical and Biophysical Research Communications, vol. 267, no. 3, pp. 777-782, 2000.

[16] T. Matsuba, M. Yano, N. Abiru et al., "Expression of recombinant human glutamic acid decarboxylase (GAD) in myeloma cells and enzyme-linked immunosorbent assay (ELISA) for autoantibodies to GAD," The Journal of Biochemistry, vol. 121, no. 1, pp. 20-24, 1997.

[17] T. Papakonstantinou, R. H. P. Law, P. Gardiner, M. J. Rowley, and I. R. Mackay, "Comparative expression and purification of human glutamic acid decarboxylase from Saccharomyces cerevisiae and Pichia pastoris," Enzyme and Microbial Technology, vol. 26, no. 9-10, pp. 645-652, 2000.

[18] A. J. Moody, K. R. Hejnaes, M. O. Marshall et al., "Isolation by anion-exchange of immunologically and enzymatically active human islet glutamic acid decarboxylase 65 overexpressed in Sf9 insect cells," Diabetologia, vol. 38, no. 1, pp. 14-23, 1995.

[19] L. Mauch, J. Seissler, H. Haubruck et al., "Baculovirus-mediated expression of human $65 \mathrm{kDa}$ and $67 \mathrm{kDa}$ glutamic acid decarboxylases in SF9 insect cells and their relevance in diagnosis of insulin-dependent diabetes mellitus," The Journal of Biochemistry, vol. 113, no. 6, pp. 699-704, 1993.

[20] X. Wang, M. Brandsma, R. Tremblay et al., "A novel expression platform for the production of diabetes-associated autoantigen human glutamic acid decarboxylase (hGAD65)," BMC Biotechnology, vol. 8, article 87, 2008.

[21] S. Ma, Y. Huang, Z. Yin, R. Menassa, J. E. Brandle, and A. M. Jevnikar, "Induction of oral tolerance to prevent diabetes with transgenic plants requires glutamic acid decarboxylase (GAD) and IL-4," Proceedings of the National Academy of Sciences of the United States of America, vol. 101, no. 15, pp. 5680-5685, 2004.

[22] A. Porceddu, A. Falorni, N. Ferradini et al., "Transgenic plants expressing human glutamic acid decarboxylase (GAD65), a major autoantigen in insulin-dependent diabetes mellitus," Molecular Breeding, vol. 5, no. 6, pp. 553-560, 1999.

[23] L. Avesani, M. Merlin, E. Gecchele et al., "Comparative analysis of different biofactories for the production of a major diabetes autoantigen," Transgenic Research, 2013.

[24] L. Avesani, A. Falorni, G. B. Tornielli et al., "Improved in planta expression of the human islet autoantigen glutamic acid decarboxylase (GAD65)," Transgenic Research, vol. 12, no. 2, pp. 203-212, 2003.

[25] L. Avesani, A. Vitale, E. Pedrazzini et al., "Recombinant human GAD65 accumulates to high levels in transgenic tobacco plants when expressed as an enzymatically inactive mutant," Plant Biotechnology Journal, vol. 8, no. 8, pp. 862-872, 2010.

[26] F. Morandini, L. Avesani, L. Bortesi et al., "Non-food/feed seeds as biofactories for the high-yield production of recombinant pharmaceuticals," Plant Biotechnology Journal, vol. 9, no. 8, pp. 911-921, 2011.

[27] M. Powell, L. Prentice, T. Asawa et al., "Glutamic acid decarboxylase autoantibody assay using 125I-labelled recombinant
GAD65 produced in yeast," Clinica Chimica Acta, vol. 256, no. 2, pp. 175-188, 1996.

[28] M. L. Papouchado, S. N. Valdez, D. Ghiringhelli, E. Poskus, and M. R. Ermácora, "Expression of properly folded human glutamate decarboxylase 65 as a fusion protein in Escherichia coli," European Journal of Biochemistry, vol. 246, no. 2, pp. 350359, 1997.

[29] X. Jiang, M. Wang, D. Y. Graham, and M. K. Estes, "Expression, self-assembly, and antigenicity of the Norwalk virus capsid protein," Journal of Virology, vol. 66, no. 11, pp. 6527-6532, 1992.

[30] B. V. Prasad, M. E. Hardy, T. Dokland, J. Bella, M. G. Rossmann, and M. K. Estes, "X-ray crystallographic structure of the Norwalk virus capsid," Science, vol. 286, no. 5438, pp. 287-290, 1999.

[31] B. V. Prasad, S. Crawford, J. A. Lawton, J. Pesavento, M. Hardy, and M. K. Estes, "Structural studies on gastroenteritis viruses," Novartis Foundation Symposium, vol. 238, pp. 26-46, 2001.

[32] M. M. Patel, M.-A. Widdowson, R. I. Glass, K. Akazawa, J. Vinjé, and U. D. Parashar, "Systematic literature review of role of noroviruses in sporadic gastroenteritis," Emerging Infectious Diseases, vol. 14, no. 8, pp. 1224-1231, 2008.

[33] E. Scallan, R. M. Hoekstra, F. J. Angulo et al., "Foodborne illness acquired in the United States-major pathogens," Emerging Infectious Diseases, vol. 17, no. 1, pp. 7-15, 2011.

[34] R. I. Glass, U. D. Parashar, and M. K. Estes, "Norovirus gastroenteritis," The New England Journal of Medicine, vol. 361, no. 18, pp. 1776-1785, 2009.

[35] S. F. Ausar, T. R. Foubert, M. H. Hudson, T. S. Vedvick, and C. R. Middaugh, "Conformational stability and disassembly of Norwalk virus-like particles: effect of $\mathrm{pH}$ and temperature," The Journal of Biological Chemistry, vol. 281, no. 28, pp. 19478-19488, 2006.

[36] J. Kissmann, S. F. Ausar, T. R. Foubert et al., "Physical stabilization of Norwalk virus-like particles," Journal of Pharmaceutical Sciences, vol. 97, no. 10, pp. 4208-4218, 2008.

[37] K. Murakami, S. Suzuki, N. Aoki et al., "Binding of norovirus virus-like particles (VLPs) to human intestinal Caco-2 cells and the suppressive effect of pasteurized bovine colostrum on this VLP binding," Bioscience, Biotechnology and Biochemistry, vol. 74, no. 3, pp. 541-547, 2010.

[38] G. T. Jennings and M. F. Bachmann, "Designing recombinant vaccines with viral properties: a rational approach to more effective vaccines," Current Molecular Medicine, vol. 7, no. 2, pp. 143-155, 2007.

[39] R. L. Atmar and M. K. Estes, "Norovirus vaccine development: next steps," Expert Review of Vaccines, vol. 11, no. 9, pp. 10231025,2012

[40] J. M. Ball, M. E. Hardy, R. L. Atmar, M. E. Conner, and M. K. Estes, "Oral immunization with recombinant Norwalk viruslike particles induces a systemic and mucosal immune response in mice," Journal of Virology, vol. 72, no. 2, pp. 1345-1353, 1998.

[41] H. S. Mason, J. M. Ball, J.-J. Shi, X. Jiang, M. K. Estes, and C. J. Arntzen, "Expression of Norwalk virus capsid protein in transgenic tobacco and potato and its oral immunogenicity in mice," Proceedings of the National Academy of Sciences of the United States of America, vol. 93, no. 11, pp. 5335-5340, 1996.

[42] R. A. Guerrero, J. M. Ball, S. S. Krater, S. E. Pacheco, J. D. Clements, and M. K. Estes, "Recombinant Norwalk virus-like particles administered intranasally to mice induce systemic and mucosal (fecal and vaginal) immune responses," Journal of Virology, vol. 75, no. 20, pp. 9713-9722, 2001. 
[43] L. S. Velasquez, S. Shira, A. N. Berta et al., "Intranasal delivery of Norwalk virus-like particles formulated in an in situ gelling, dry powder vaccine," Vaccine, vol. 29, no. 32, pp. 5221-5231, 2011.

[44] J. M. Ball, D. Y. Graham, A. R. Opekun, M. A. Gilger, R. A. Guerrero, and M. K. Estes, "Recombinant Norwalk virus-like particles given orally to volunteers: phase I study," Gastroenterology, vol. 117, no. 1, pp. 40-48, 1999.

[45] C. O. Tacket, H. S. Mason, G. Losonsky, M. K. Estes, M. M. Levine, and C. J. Arntzen, "Human immune responses to a novel Norwalk virus vaccine delivered in transgenic potatoes," Journal of Infectious Diseases, vol. 182, no. 1, pp. 302-305, 2000.

[46] C. O. Tacket, M. B. Sztein, G. A. Losonsky, S. S. Wasserman, and M. K. Estes, "Humoral, mucosal, and cellular immune responses to oral Norwalk virus-like particles in volunteers," Clinical Immunology, vol. 108, no. 3, pp. 241-247, 2003.

[47] S. S. El-Kamary, M. F. Pasetti, P. M. Mendelman et al., "Adjuvanted intranasal Norwalk virus-like particle vaccine elicits antibodies and antibody-secreting cells that express homing receptors for mucosal and peripheral lymphoid tissues," Journal of Infectious Diseases, vol. 202, no. 11, pp. 1649-1658, 2010.

[48] R. L. Atmar, D. I. Bernstein, C. D. Harro et al., "Norovirus vaccine against experimental human Norwalk virus illness," The New England Journal of Medicine, vol. 365, no. 23, pp. 2178-2187, 2011.

[49] T. Yoda, Y. Terano, Y. Suzuki et al., "Characterization of monoclonal antibodies generated against Norwalk virus GII capsid protein expressed in Escherichia coli," Microbiology and Immunology, vol. 44, no. 11, pp. 905-914, 2000.

[50] M. Xia, T. Farkas, and X. Jiang, "Norovirus capsid protein expressed in yeast forms virus-like particles and stimulates systemic and mucosal immunity in mice following an oral administration of raw yeast extracts," Journal of Medical Virology, vol. 79, no. 1, pp. 74-83, 2007.

[51] R. S. Baric, B. Yount, L. Lindesmith et al., "Expression and self-assembly of Norwalk virus capsid protein from Venezuelan equine encephalitis virus replicons," Journal of Virology, vol. 76, no. 6, pp. 3023-3030, 2002.

[52] P. R. Harrington, B. Yount, R. E. Johnston, N. Davis, C. Moe, and R. S. Baric, "Systemic, mucosal, and heterotypic immune induction in mice inoculated with Venezuelan equine encephalitis replicons expressing Norwalk virus-like particles," Journal of Virology, vol. 76, no. 2, pp. 730-742, 2002.

[53] X. Zhang, N. A. Buehner, A. M. Hutson, M. K. Estes, and H. S. Mason, "Tomato is a highly effective vehicle for expression and oral immunization with Norwalk virus capsid protein," Plant Biotechnology Journal, vol. 4, no. 4, pp. 419-432, 2006.

[54] L. Santi, L. Batchelor, Z. Huang et al., "An efficient plant viral expression system generating orally immunogenic Norwalk virus-like particles," Vaccine, vol. 26, no. 15, pp. 1846-1854, 2008.

[55] Z. Huang, Q. Chen, B. Hjelm, C. Arntzen, and H. Mason, "A DNA replicon system for rapid high-level production of viruslike particles in plants," Biotechnology and Bioengineering, vol. 103, no. 4, pp. 706-714, 2009.

[56] H. Lai, J. He, M. Engle, M. S. Diamond, and Q. Chen, "Robust production of virus-like particles and monoclonal antibodies with geminiviral replicon vectors in lettuce," Plant Biotechnology Journal, vol. 10, no. 1, pp. 95-104, 2012.

[57] A. C. Souza, R. M. Vasques, A. K. Inoue-Nagata et al., "Expression and assembly of Norwalk virus-like particles in plants using a viral RNA silencing suppressor gene," Applied Microbiology and Biotechnology, vol. 97, no. 20, pp. 9021-9027, 2013.
[58] M. Herbst-Kralovetz, H. S. Mason, and Q. Chen, "Norwalk virus-like particles as vaccines," Expert Review of Vaccines, vol. 9, no. 3, pp. 299-307, 2010.

[59] H. Lai and Q. Chen, "Bioprocessing of plant-derived virus-like particles of Norwalk virus capsid protein under current Good Manufacture Practice regulations," Plant Cell Reports, vol. 31, no. 3, pp. 573-584, 2012.

[60] A. Buchacher, R. Predl, K. Strutzenberger et al., "Generation of human monoclonal antibodies against HIV-1 proteins: electrofusion and Epstein-Barr virus transformation for peripheral blood lymphocyte immortalization," AIDS Research and Human Retroviruses, vol. 10, no. 4, pp. 359-369, 1994.

[61] A. Trkola, A. B. Pomales, H. Yuan et al., "Cross-clade neutralization of primary isolates of human immunodeficiency virus type 1 by human monoclonal antibodies and tetrameric CD4-IgG," Journal of Virology, vol. 69, no. 11, pp. 6609-6617, 1995.

[62] A. Trkola, M. Purtscher, T. Muster et al., "Human monoclonal antibody 2G12 defines a distinctive neutralization epitope on the gp120 glycoprotein of human immunodeficiency virus type 1," Journal of Virology, vol. 70, no. 2, pp. 1100-1108, 1996.

[63] J. R. Mascola, "Passive transfer studies to elucidate the role of antibody-mediated protection against HIV-1," Vaccine, vol. 20, no. 15, pp. 1922-1925, 2002.

[64] R. S. Veazey, R. J. Shattock, M. Pope et al., "Prevention of virus transmission to macaque monkeys by a vaginally applied monoclonal antibody to HIV-1 gp120," Nature Medicine, vol. 9, no. 3, pp. 343-346, 2003.

[65] C. Armbruster, G. M. Stiegler, B. A. Vcelar et al., "A phase I trial with two human monoclonal antibodies (hMAb 2F5, 2G12) against HIV-1," AIDS, vol. 16, no. 2, pp. 227-233, 2002.

[66] G. Stiegler, C. Armbruster, B. Vcelar et al., "Antiviral activity of the neutralizing antibodies 2F5 and 2G12 in asymptomatic HIV1-infected humans: a phase I evaluation," AIDS, vol. 16, no. 15, pp. 2019-2025, 2002.

[67] A. Trkola, H. Kuster, P. Rusert et al., "Delay of HIV-1 rebound after cessation of antiretroviral therapy through passive transfer of human neutralizing antibodies," Nature Medicine, vol. 11, no. 6, pp. 615-622, 2005.

[68] B. Joos, A. Trkola, H. Kuster et al., "Long-term multiple-dose pharmacokinetics of human monoclonal antibodies (MAbs) against human immunodeficiency virus type 1 envelope gp120 (MAb 2G12) and gp41 (MAbs 4E10 and 2F5)," Antimicrobial Agents and Chemotherapy, vol. 50, no. 5, pp. 1773-1779, 2006.

[69] P. J. Klasse, R. Shattock, and J. P. Moore, "Antiretroviral drugbased microbicides to prevent HIV-1 sexual transmission," Annual Review of Medicine, vol. 59, pp. 455-471, 2008.

[70] T. Rademacher, M. Sack, E. Arcalis et al., "Recombinant antibody $2 \mathrm{G} 12$ produced in maize endosperm efficiently neutralizes HIV-1 and contains predominantly single-GlcNAc N-glycans," Plant Biotechnology Journal, vol. 6, no. 2, pp. 189-201, 2008.

[71] R. Kunert, F. Rüker, and H. Katinger, "Molecular characterization of five neutralizing anti-HIV type 1 antibodies: identification of nonconventional D segments in the human monoclonal antibodies 2G12 and 2F5," AIDS Research and Human Retroviruses, vol. 14, no. 13, pp. 1115-1128, 1998.

[72] E. Arcalis, J. Stadlmann, T. Rademacher et al., "Plant species and organ influence the structure and subcellular localization of recombinant glycoproteins," Plant Molecular Biology, vol. 83, no. 1-2, pp. 105-117, 2013.

[73] M. Schähs, R. Strasser, J. Stadlmann, R. Kunert, T. Rademacher, and H. Steinkellner, "Production of a monoclonal antibody 
in plants with a humanized $N$-glycosylation pattern," Plant Biotechnology Journal, vol. 5, no. 5, pp. 657-663, 2007.

[74] R. Strasser, F. Altmann, L. Mach, J. Glössl, and H. Steinkellner, "Generation of Arabidopsis thaliana plants with complex Nglycans lacking $\beta 1,2$-linked xylose and core $\alpha 1,3$-linked fucose," FEBS Letters, vol. 561, no. 1-3, pp. 132-136, 2004.

[75] A. Loos, B. van Droogenbroeck, S. Hillmer et al., "Production of monoclonal antibodies with a controlled $N$-glycosylation pattern in seeds of Arabidopsis thaliana," Plant Biotechnology Journal, vol. 9, no. 2, pp. 179-192, 2011.

[76] K. Ramessar, T. Rademacher, M. Sack et al., "Cost-effective production of a vaginal protein microbicide to prevent HIV transmission," Proceedings of the National Academy of Sciences of the United States of America, vol. 105, no. 10, pp. 3727-3732, 2008.

[77] R. Strasser, J. Stadlmann, M. Schähs et al., "Generation of glyco-engineered Nicotiana benthamiana for the production of monoclonal antibodies with a homogeneous human-like $N$ glycan structure," Plant Biotechnology Journal, vol. 6, no. 4, pp. 392-402, 2008.

[78] Y. Rosenberg, M. Sack, D. Montefiori et al., "Rapid high-level production of functional HIV broadly neutralizing monoclonal antibodies in transient plant expression systems," PLoS ONE, vol. 8, no. 3, Article ID e58724, 2013.

[79] F. Sainsbury, M. Sack, J. Stadlmann, H. Quendler, R. Fischer, and G. P. Lomonossoff, "Rapid transient production in plants by replicating and non-replicating vectors yields high quality functional anti-HIV antibody," PLoS ONE, vol. 5, no. 11, Article ID e13976, 2010.

[80] D. M. Floss, M. Sack, E. Arcalis et al., "Influence of elastin-like peptide fusions on the quantity and quality of a tobacco-derived human immunodeficiency virus-neutralizing antibody," Plant Biotechnology Journal, vol. 7, no. 9, pp. 899-913, 2009.

[81] T. Holland, M. Sack, T. Rademacher et al., "Optimal nitrogen supply as a key to increased and sustained production of a monoclonal full-size antibody in BY-2 suspension culture," Biotechnology and Bioengineering, vol. 107, no. 2, pp. 278-289, 2010.

[82] D. E. Meyer and A. Chilkoti, "Purification of recombinant proteins by fusion with thermally-responsive polypeptides," Nature Biotechnology, vol. 17, no. 11, pp. 1112-1115, 1999.

[83] D. Platis, J. Drossard, R. Fischer, J. K.-C. Ma, and N. E. Labrou, "New downstream processing strategy for the purification of monoclonal antibodies from transgenic tobacco plants," Journal of Chromatography A, vol. 1211, no. 1-2, pp. 80-89, 2008.

[84] M. Mihara, M. Hashizume, H. Yoshida, M. Suzuki, and M. Shiina, "IL-6/IL-6 receptor system and its role in physiological and pathological conditions," Clinical Science, vol.122, no. 4, pp. 143-159, 2012.

[85] M. A. Febbraio and B. K. Pedersen, "Contraction-induced myokine production and release: is skeletal muscle an endocrine organ?" Exercise and Sport Sciences Reviews, vol. 33, no. 3, pp. 114-119, 2005.

[86] A. M. W. Petersen and B. K. Pedersen, "The anti-inflammatory effect of exercise," Journal of Applied Physiology, vol. 98, no. 4, pp. 1154-1162, 2005.

[87] J. S. Smolen and R. N. Maini, "Interleukin-6: a new therapeutic target," Arthritis Research \& Therapy, vol. 8, supplement 2, article S5, 2006.

[88] M. Madan, B. Bishayi, M. Hoge, and S. Amar, "Atheroprotective role of interleukin-6 in diet- and/or pathogen-associated atherosclerosis using an ApoE heterozygote murine model," Atherosclerosis, vol. 197, no. 2, pp. 504-514, 2008.

[89] W. Swardfager, K. Lanctôt, L. Rothenburg, A. Wong, J. Cappell, and N. Herrmann, "A meta-analysis of cytokines in Alzheimer's disease," Biological Psychiatry, vol. 68, no. 10, pp. 930-941, 2010.

[90] A. Maccio and C. Madeddu, "The role of interleukin-6 in the evolution of ovarian cancer: clinical and prognostic implications-a review," Journal of Molecular Medicine, vol. 91, no. 12, pp. 1355-1368, 2013.

[91] P. D. Ziakas, P. Karsaliakos, M. L. Prodromou, and E. Mylonakis, "Interleukin-6 polymorphisms and hematologic malignancy: a re-appraisal of evidence from genetic association studies," Biomarkers, vol. 18, no. 7, pp. 625-631, 2013.

[92] T. Hirano, T. Taga, N. Nakano et al., "Purification to homogeneity and characterization of human B-cell differentiation factor (BCDF or BSFp-2)," Proceedings of the National Academy of Sciences of the United States of America, vol. 82, no. 16, pp. 54905494, 1985.

[93] T. Hirano, T. Taga, K. Yasukawa et al., "Human B-cell differentiation factor defined by an anti-peptide antibody and its possible role in autoantibody production," Proceedings of the National Academy of Sciences of the United States of America, vol. 84, no. 1, pp. 228-231, 1987.

[94] F. R. Balkwill, "Re: possible role of ovarian epithelial inflammation in ovarian cancer," Journal of the National Cancer Institute, vol. 92, no. 2, pp. 162a-163a, 2000.

[95] N. Nishimoto, "Interleukin-6 as a therapeutic target in candidate inflammatory diseases," Clinical Pharmacology \& Therapeutics, vol. 87, no. 4, pp. 483-487, 2010.

[96] X. Yao, J. Huang, H. Zhong et al., “Targeting interleukin-6 in inflammatory autoimmune diseases and cancers," Pharmacology \& Therapeutics, vol. 141, no. 2, pp. 125-139, 2014.

[97] N. Tonouchi, N. Oouchi, N. Kashima et al., "High-level expression of human BSF-2/IL-6 cDNA in Escherichia coli using a new type of expression-preparation system," The Journal of Biochemistry, vol. 104, no. 1, pp. 30-34, 1988.

[98] H. Yasueda, K. Nagase, A. Hosoda, Y. Akiyama, and K. Yamada, "High-level direct expression of semi-synthetic human interleukin-6 in Escherichia coli and production of N-terminus met-free product," Nature Biotechnology, vol. 8, no. 11, pp. 10361040, 1990.

[99] D. Ejima, M. Watanabe, Y. Sato, M. Date, N. Yamada, and Y. Takahara, "High yield refolding and purification process for recombinant human interleukin-6 expressed in Escherichia coli," Biotechnology and Bioengineering, vol. 62, no. 3, pp. 301310, 1999.

[100] I. Barthelemy, G. G. de Buitrago, C. Carreiro et al., "Production and secretion of human interleukin 6 into the periplasm of Escherichia coli: efficient processing of N-terminal variants of hIL6 by the E. coli signal peptidase," Journal of Biotechnology, vol. 27, no. 3, pp. 307-316, 1993.

[101] Y. Li, C. X. Chen, B.-U. von Specht, and H. P. Hahn, "Cloning and hemolysin-mediated secretory expression of a codonoptimized synthetic human interleukin-6 gene in Escherichia coli," Protein Expression and Purification, vol. 25, no. 3, pp. 437447, 2002.

[102] T. W. Kim, B. H. Chung, and Y. K. Chang, "Production of soluble human interleukin- 6 in cytoplasm by fed-batch culture of recombinant E. coli," Biotechnology Progress, vol. 21, no. 2, pp. 524-531, 2005.

[103] H. Nausch, J. Huckauf, R. Koslowski, U. Meyer, I. Broer, and H. Mikschofsky, "Recombinant production of human interleukin 
6 in Escherichia coli," PLoS ONE, vol. 8, no. 1, Article ID e54933, 2013.

[104] H. Li, Y. Wang, A. Xu, S. Li, S. Jin, and D. Wu, "Large-scale production, purification and bioactivity assay of recombinant human interleukin-6 in the methylotrophic yeast Pichia pastoris," FEMS Yeast Research, vol. 11, no. 2, pp. 160-167, 2011.

[105] Y. Matsuura, M. Tatsumi, K. Enami, S. Morikawa, S. Yamazaki, and M. Kohase, "Expression of IL-6/IFN- $\beta 2$ in a baculovirus system and its biological function," Annals of the New York Academy of Sciences, vol. 557, pp. 122-129, 1989.

[106] C. W. Zhao, J. X. Wang, D. H. Xiao, and X. K. Ma, "Molecular cloning and expression of human interleukin-6 in insect cells," Science in China B, vol. 37, no. 9, pp. 1073-1081, 1994.

[107] S. Y. Kwon, Y. Yang, C. B. Hong, and K. H. Pyun, "Expression of active human interleukin-6 in transgenic tobacco," Molecules and Cells, vol. 5, pp. 486-492, 1995.

[108] H. Nausch, H. Mikschofsky, R. Koslowski, U. Meyer, I. Broer, and J. Huckauf, "High-level transient expression of ER-targeted human interleukin 6 in Nicotiana benthamiana," PLoS ONE, vol. 7, no. 11, Article ID e48938, 2012.

[109] V. Pantaleo, "Plant RNA silencing in viral defence," Advances in Experimental Medicine and Biology, vol. 722, pp. 39-58, 2011.

[110] Y. Shoji, C. E. Farrance, J. Bautista et al., "A plant-based system for rapid production of influenza vaccine antigens," Influenza and other Respiratory Viruses, vol. 6, no. 3, pp. 204-210, 2012.

[111] M. Bendandi, S. Marillonnet, R. Kandzia et al., "Rapid, highyield production in plants of individualized idiotype vaccines for non-Hodgkin's lymphoma," Annals of Oncology, vol. 21, no. 12, pp. 2420-2427, 2010.

[112] Y. Shaaltiel, D. Bartfeld, S. Hashmueli et al., "Production of glucocerebrosidase with terminal mannose glycans for enzyme replacement therapy of Gaucher's disease using a plant cell system," Plant Biotechnology Journal, vol. 5, no. 5, pp. 579-590, 2007.

[113] A. A. McCormick, S. J. Reinl, T. I. Cameron et al., "Individualized human scFv vaccines produced in plants: humoral antiidiotype responses in vaccinated mice confirm relevance to the tumor Ig," Journal of Immunological Methods, vol. 278, no. 1-2, pp. 95-104, 2003.

[114] V. Gomord, A.-C. Fitchette, L. Menu-Bouaouiche et al., "Plantspecific glycosylation patterns in the context of therapeutic protein production," Plant Biotechnology Journal, vol. 8, no. 5, pp. 564-587, 2010.

[115] I. Murillo, R. Roca, C. Bortolotti, and B. S. Segundo, "Engineering photoassimilate partitioning in tobacco plants improves growth and productivity and provides pathogen resistance," Plant Journal, vol. 36, no. 3, pp. 330-341, 2003.

[116] M. C. Ruebelt, M. Lipp, T. L. Reynolds et al., "Application of two-dimensional gel electrophoresis to interrogate alterations in the proteome of gentically modified crops-3. Assessing unintended effects," Journal of Agricultural and Food Chemistry, vol. 54, no. 6, pp. 2169-2177, 2006.

[117] R. M. Twyman, S. Schillberg, and R. Fischer, "Transgenic plants in the biopharmaceutical market," Expert Opinion on Emerging Drugs, vol. 10, no. 1, pp. 185-218, 2005.

[118] H. Daniell, N. D. Singh, H. Mason, and S. J. Streatfield, "Plantmade vaccine antigens and biopharmaceuticals," Trends in Plant Science, vol. 14, no. 12, pp. 669-679, 2009.

[119] S. Gupta, A. Jain, M. Chakraborty, J. K. Sahni, J. Ali, and S. Dang, "Oral delivery of therapeutic proteins and peptides: a review on recent development," Drug Delivery, vol. 20, no. 6, pp. 237-246, 2013. 

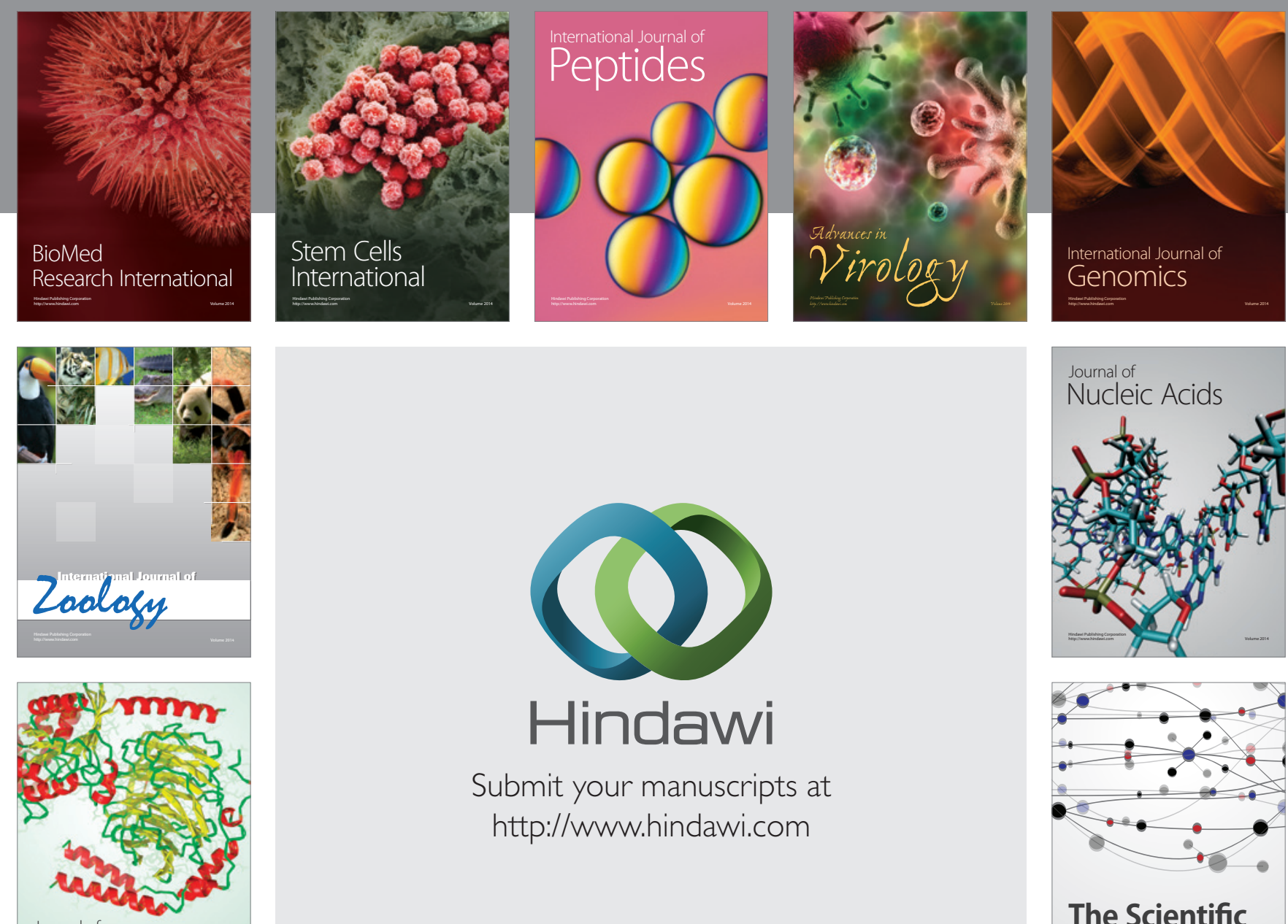

Submit your manuscripts at

http://www.hindawi.com

Journal of
Signal Transduction
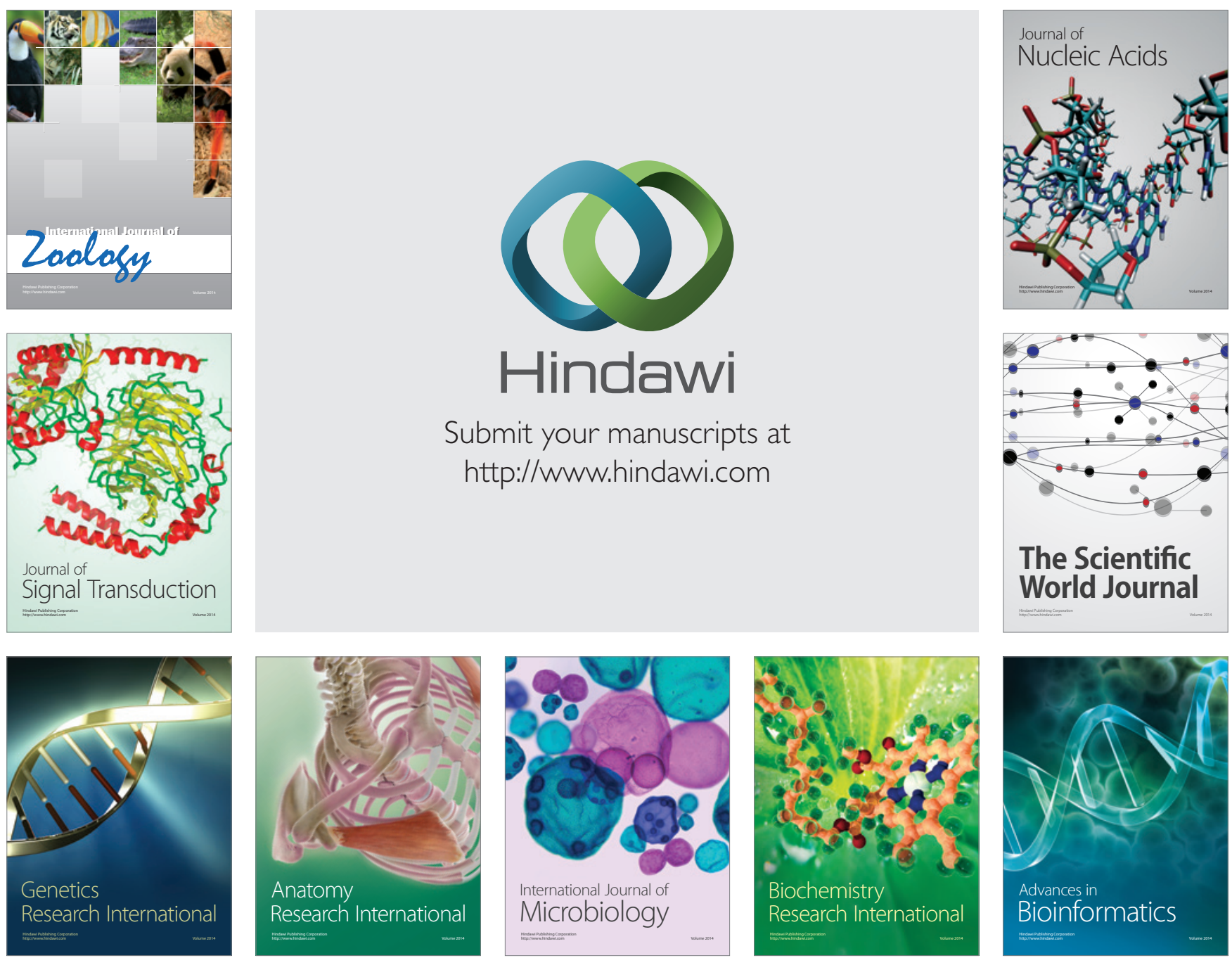

The Scientific World Journal
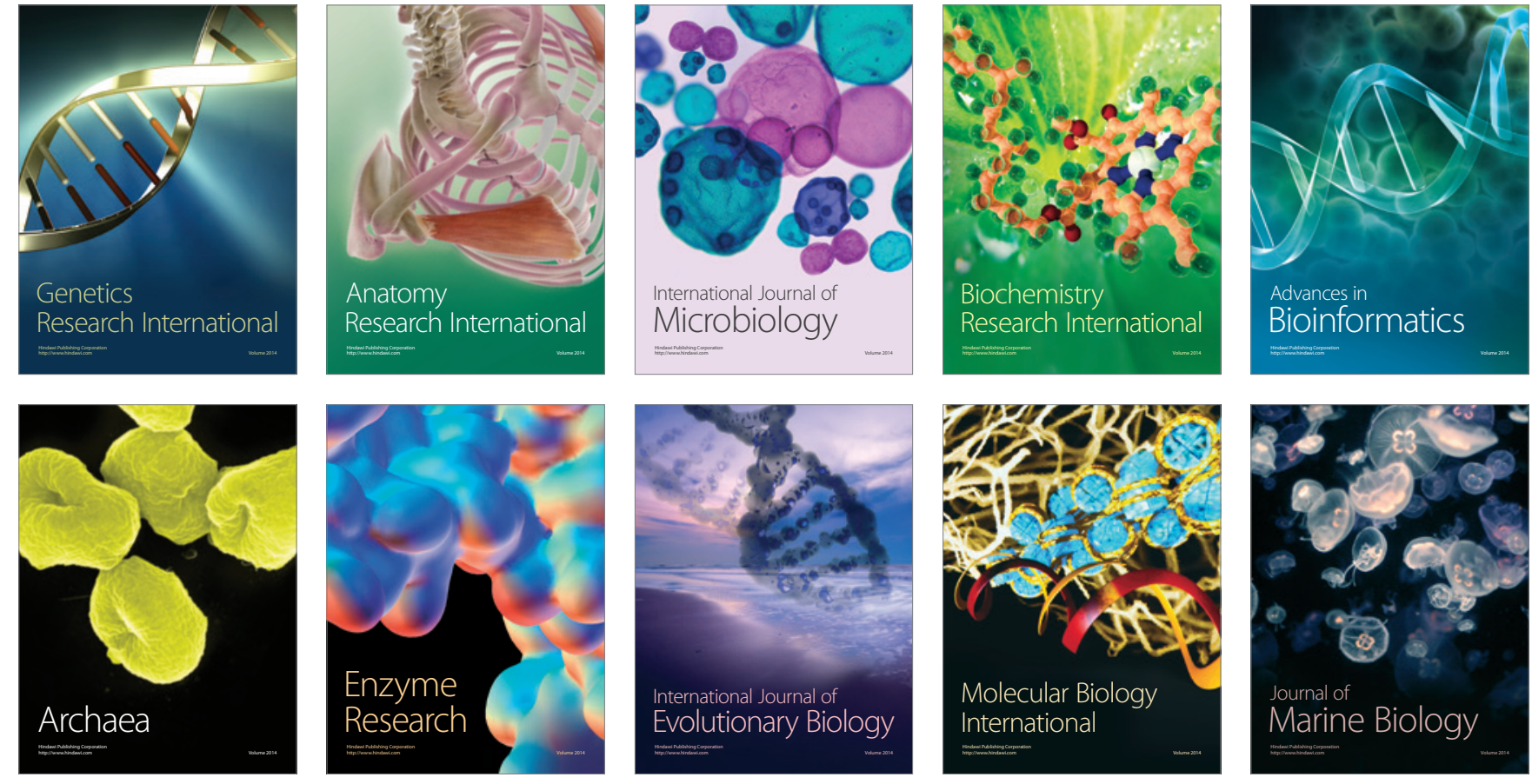